\title{
PORTUGUESE VINES AND WINES: HERITAGE, QUALITY SYMBOL, TOURISM ASSET
}

\section{A VINHA: UM PATRIMÓNIO, UM SÍMBOLO DE QUALIDADE, UM TRUNFO TURÍSTICO}

\section{A. Lavrador da Silva ${ }^{1}$, , M. João Fernão-Pires ${ }^{2}$, F. Bianchi-de-Aguiar3}

\author{
${ }^{1}$ Universidade Nova de Lisboa and Universidade de Lisboa, Avenida de Berna, 26-C / 1069-061 Lisboa \\ ${ }^{2}$ Instituto da Vinha e do Vinho, I.P. (Portugal), R. Mouzinho da Silveira 5, 1250-165 Lisboa \\ ${ }^{3}$ Universidade de Trás-os-Montes e Alto Douro and Honorary President of the OIV, Quinta de Prados5000-801 Vila Real \\ *corresponding author: Tel: +00351 962383275, email: algeo@fcsh.unl.pt
}

(Received 06.08.2017. Accepted 28.02.2018)

\section{SUMMARY}

This paper aims to showcase the value and uniqueness of Portuguese wines and wine regions. It has three independent but related parts. The first part focuses the millenary history of vines in Portugal and stresses their value for the regional and national economy. The second part focuses on the role of brands in the wine regions and wine marketing, highlighting the importance of the landscape in promotion. It is claimed that the use of landmarks can help create an identity image, useful for attracting tourism and wine advertising, being also a major asset for the Portuguese world trade of wines. Landmarks identification and promotional suggestions with landmarks related to Portuguese wine regions are presented. The third part presents a short revision of the panorama of wine tourism in Portugal and stresses the role of landscapes in its promotion. A literary route in the Douro Demarcated Region is presented by way of example.

\section{RESUMO}

Este artigo pretende evidenciar o valor e a unicidade dos vinhos e das regiões vitivinícolas de Portugal. O artigo está dividido em três partes independentes, mas que se interrelacionam. A primeira parte diz respeito à história milenar da vinha em Portugal e sublinha o valor que representa para a economia regional e nacional. A segunda parte, refere o valor das marcas vínicas no marketing dos vinhos e das regiões vinhateiras, destacando a importância da paisagem na promoção. Defende-se que o uso de elementos territoriais distintivos (landmarks) ajuda a criar uma imagem identitária para as regiões vinhateiras que é útil ao turismo e à implantação do vinho português no mercado global. São identificadas landmarks para cinco emblemáticas regiões vinhateiras de Portugal e apresentam-se sugestões para a sua utilização na promoção. A terceira parte integra uma breve revisão ao panorama do enoturismo em Portugal, destacando o valor da paisagem na sua divulgação. Como exemplo de aplicação é mencionada uma rota com a paisagem e a literatura, na Região Demarcada do Douro.

Key words: heritage, vineyards, landscape, brands, tourism, itineraries.

Palavras-chave: património, vinhas, paisagem, marcas, turismo, itinerários.

\section{INTRODUCTION}

Vineyards are one of the most emblematic icons of Mediterranean landscapes. Their environmental, cultural and identity value is widely acknowledged, with particular socioeconomic significance in Portugal. Nowadays in Europe and in Portugal, changes in technology, new demands of the global market and the impact of European Agrarian Policies imply significant changes in landscapes, especially in territories which are well-adjusted to vine plantation, such as Geographical Indications (PGI) and
Denomination of Origin (PDO). These changes represent environmental damages linked to the significant growing of vineyard surface and heritage losses, with emphasis on the alteration of the traditional conduction systems of the vines and terracing of the slopes, destruction of vine agricultural practices and replacement of instruments and artefacts which are sometimes thousands of years old. To this we must add the loss of symbolic and immaterial identity values, namely rituals and feasts which are disappearing with the abandonment of the countryside by successive rural generations and the arrival of

This is an Open Access article distributed under the terms of the Creative Commons Attribution License

(http://creativecommons.org/licenses/by/4.0), which permits unrestricted use, distribution, and reproduction in any medium, provided the original work is properly cited. 
often younger urbanites, with new mentalities, ways of living and acting. Adjusted political and economic support has to be implemented to help these outsider stakeholders stop the cultural collapse, and, instead, to take benefit from the said culture.

In this context, the qualification of the European wine regions and wines is crucial to the success of the wine sector and the wine regions, namely through tourism. The qualification process involves landscapes qualification that implies the defence of its unique elements (landmarks), which are the result of natural environment and civilizational background, and of the art of producing and trading in wines with a terroir signature. The aim is to link the quality of the terroirs with the quality of wines, instead of making wines by resorting to the growing potential of chemical industry and mechanical engineering, which currently prevails. The recognition of vineyard heritages by UNESCO, such as the Douro Valley (Continental Portugal) and the vines of the Pico island (Azores, Portugal), are a step in this direction. These recommendations are also highlighted by the Landscape European Convention (EC, 2000), underlining the role of landscapes in the implementation of new ideas and actions to create value and differentiation for wine regions. These actions involve compromises between stakeholders and political actors, to analyse and to promote practices and customs and to protect sustainable mosaics. The recognition of landmarks is crucial to this objective, as well as to implement an accurate planning and management of the wine territories on a multifunctional basis ${ }^{1}$.

Taking this into account, this paper aims to provide both reflection and a warning, focusing on: a) the Portuguese viniculture heritage; b) the value of landmarks and wine brands as opportunities for the wine regions and for wine marketing; c) the landscape in the development of Portuguese wine tourism and promotion of wine regions.

${ }^{1}$ In the Portuguese vine panorama there are internationally recognised examples that should be replicated, such as the Duorum Vinhos S.A., project, by the João Portugal Ramos Wines Group, created in 2007. In 2015 it was the European winner of the prestigious 'Anders Wall' prize (http://www.boasnoticias.pt/noticias, consulted in June 2015), that distinguishes the best project in rural landscape management each year. That project aims to improve the historical viniculture of the Porto and Douro Demarcated Region, concerning the regeneration of viticulture heritage and of the natural heritage and biodiversity, and also creates job opportunities in tourism.

\section{The value of Portuguese viticulture heritage}

\subsection{Portugal as a reserve of varietal biodiversity}

Today, the vine (Vitis vinifera) is spread all over the world, in line with its recognized economic value. Under favourable environmental conditions, vine culture can last thousands of years whereas in advantageous territories, vines benefit from modern technology (Figure 1).

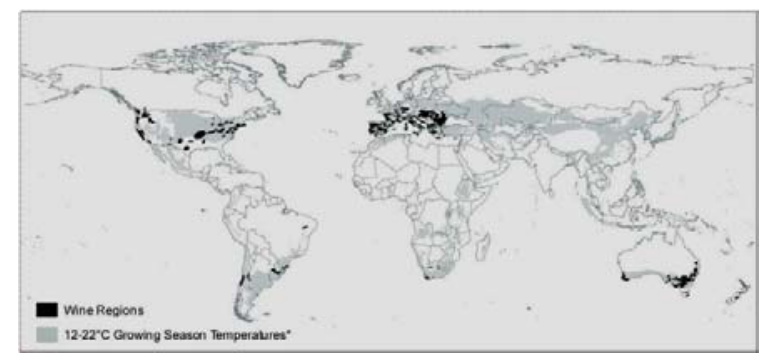

Figure 1. World viticulture regions and growing season temperatures (April to October, in the Northern Hemisphere; October to April, in the Southern Hemisphere). Adapted from Jones (2013).

Regiões vitícolas mundiais e zonas com isotérmicas de $12-22^{\circ} \mathrm{C}$ para o ciclo vegetativo (Abril a Outubro, no Hemisfério Norte; Outubro a Abril, no Hemisfério Sul).

In Portugal vines are the main agrarian culture, covering 198,684 hectares in Continental Portugal, 1700 hectares in Madeira and 1061 hectares in Azores (IVV, 2015), representing about $15 \%$ of the Portuguese Agriculture Land Used (INE, 2013). The economic value (base price production) of vines (wine and table grapes) represents $12 \%$ of the total land cultivation of the country (INE, 2015). Considering exports, the numbers are also remarkable (Table I). In tourism, the Wines and Food sector figures among the top ten strategic products for the Portuguese economy (Turismo de Portugal, 2014).

Table I

Portuguese wines exports between 2011 and 2016

Exportação de vinhos em Portugal entre 2011 e 2016

\begin{tabular}{|c|c|c|c|c|c|c|c|c|c|c|c|c|}
\hline & \multicolumn{2}{|c|}{2011} & \multicolumn{2}{|c|}{2012} & \multicolumn{2}{|c|}{2013} & \multicolumn{2}{|c|}{2014} & \multicolumn{2}{|c|}{2015} & \multicolumn{2}{|c|}{2016} \\
\hline & $\mathrm{hL}$ & $\%$ & $\mathrm{hL}$ & $\%$ & $\mathrm{hL}$ & $\%$ & $\mathrm{hL}$ & $\%$ & $\mathrm{hL}$ & $\%$ & $\mathrm{hL}$ & $\%$ \\
\hline Europe & 965.110 & 42.8 & 1.150 .310 & 45.4 & 956.875 & 42.6 & 1381639 & 36.0 & 1403447 & 50.1 & 1638658 & 59.1 \\
\hline World & 1.289 .180 & 57.2 & 1.384 .131 & 54.6 & 129.496 & 57.4 & 1.345 .387 & 64.0 & 1396380 & 49.9 & 1133220 & 40.9 \\
\hline
\end{tabular}

Source: IVV (2017). 
The existence of a significant varietal heritage, in number and quality, corresponding to important terroir diversity and wines with recognized international prestige is particularly meaningful for the success of vineyards. Wild vines (Vitis sylvestris) can still be found in the Iberian Peninsula, in particular on the borders of the rivers of Andalusia and the Basque Country, in Spain, and in the river basins of the Sado, Guadiana, Tejo and Odelouca rivers, in the South Portugal, currently under sustained threat from the construction of dams and riverbank interventions (Figure 2). In fact, "there is a strong possibility that the Iberian Peninsula was a native centre of the Vitis vinifera" (Arroyo-García et al., 2006; Martins and Graça, 2014).

The wealth of vine varieties in Portugal (Figure 3 ) is particularly relevant at the world scale, in which there are currently less than 50 vine varieties (Fregoni, 2010), a dramatic reality for the preservation of the diversity of vines and their potential adaptability.
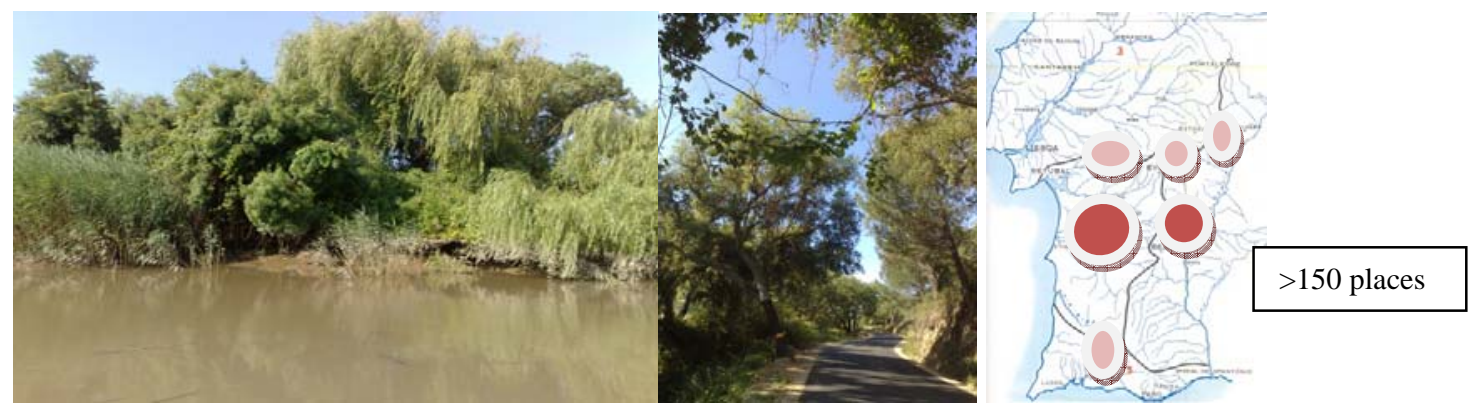

Figure 2. Location of Vitis silvestris in Portugal. Photography (courtesy of Antero Martins); Map (adapted from Martins and Graça, 2014) Localização de videiras selvagens (Vitis silvestris) em Portugal.

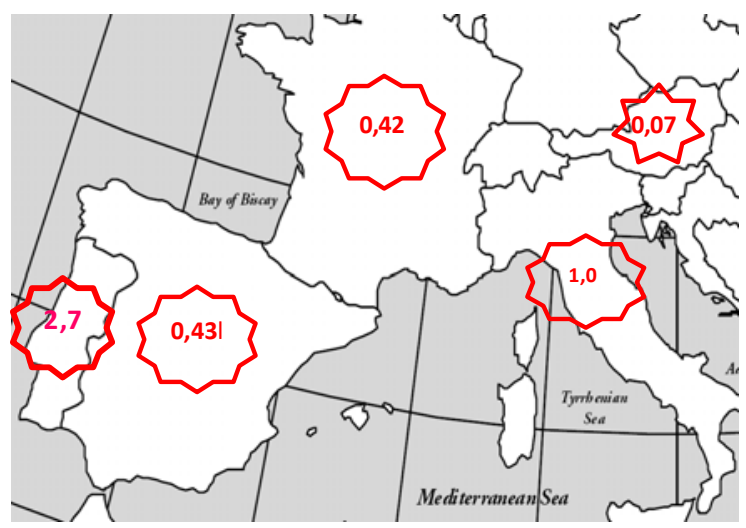

Figure 3. Portugal has world primacy regarding wealth of varieties of Vitis vinifera (Martins and Graça, 2014). Number of indigenous varieties per $1.000 \mathrm{~km}^{2}$

Portugal tem primazia mundial na riqueza varietal de castas de Vitis vinifera.

The number and quality of the main varieties used in the Portuguese "Geographical Indications" and "Denominations of Origin" is remarkable, 34 main varieties are used (representation above 1\%) in $89 \%$ of the total vine area. Reds are prevalent, with 18 varieties covering $61 \%$ of the total area, two of which are international varieties. There are 16 main white varieties, all of them national, occupying $28 \%$ of the total area (IVV, 2016, Table II).
Since $1978^{2}$ there has been a big effort on the part of Portuguese technicians and institutions to characterize, select and preserve the vine varieties (Table III). Cloning studies, rather than the usual health care studies, are the norm, permitting the identification of unknown varieties; comparative study of all varieties; experimental work with different varieties; diffusion of results and promotion of the unique quality and diversity of the Portuguese 
varieties $^{3}$. These technical and scientific contributions in Portugal today are highly effective, from a methodological point of view, and achieve an unrivalled scale in the world of viticulture, generating large-scale capital gains and having enormous potential for the future.

2 This work was begun by an informal network composed of Universities, the Ministry of Agriculture, wine companies' associations and, since 2009, has been led by the Portuguese Association for Vine Diversity (PORVID). Pioneering works linked to vine taxonomy stand out (Eiras-Dias et al., 1989), as do characterization of vines and synonymy confirmation by DNA markers (Lopes et al., 1999). In this millennium, molecular characterization (Santos, 2000, in Magalhães, 2008), the listing of the better adapted Portuguese varieties (Pinto Carnide, 2003, in Magalhães, 2008) and the enormous production of polyclonal materials and clones, with application in viticulture modernization through the use of autochthonous varieties the main focus.

3 In the Experimental Centre for the Conservation of the Autochthonous Vineyard, created by PORVID (Pegões-Portugal), more than 25,000 clones are planted from more than 100 autochthonous varieties, about 15,000 are preserved in pots (with an equal amount in collections all over the country), representing the diversity of 200 autochthonous varieties. The goal is to reach the target of 50 thousand clones from 250 varieties (courtesy of Eng. Antero Martins).

\section{Table II}

List of the varieties most used in Portugal

Lista das castas mais utilizadas em Portugal

\begin{tabular}{|c|c|c|c|}
\hline VARIETY & Color & $\begin{array}{c}\text { Area } \\
\text { (ha) }\end{array}$ & $\%$ \\
\hline Aragonez / Tinta Roriz / Tempranillo & Red & 19.267 & 10 \\
\hline Touriga Franca & Red & 16.372 & 8 \\
\hline Castelão / João de Santarém / Periquita & Red & 13.849 & 7 \\
\hline Fernão Pires / Maria Gomes & White & 13.789 & 7 \\
\hline Touriga Nacional & Red & 13.168 & 7 \\
\hline Trincadeira / Tinta Amarela / Trincadeira Preta & Red & 11.365 & 6 \\
\hline Baga & Red & 7.234 & 4 \\
\hline Síria / Roupeiro / Códega & White & 6.979 & 4 \\
\hline Arinto / Pedernã & White & 6.414 & 3 \\
\hline Alicante Bouschet & Red & 5.522 & 3 \\
\hline Loureiro & White & 5.506 & 3 \\
\hline Syrah / Shiraz & Red & 5.295 & 3 \\
\hline Tinta Barroca & Red & 5.227 & 3 \\
\hline Vinhão / Sousão & Red & 4.530 & 2 \\
\hline Alvarinho & White & 3.464 & 2 \\
\hline Malvasia Fina / Boal & White & 3.226 & 2 \\
\hline Rufete / Tinta Pinheira & Red & 3.030 & 2 \\
\hline Marufo / Mourisco Roxo & Red & 2.942 & 1 \\
\hline Jaen / Mencia & Red & 2.779 & 1 \\
\hline Malvasia Rei & White & 2.776 & 1 \\
\hline Caladoc & Red & 2.761 & 1 \\
\hline Cabernet Sauvignon & Red & 2.649 & 1 \\
\hline Rabigato & White & 2.350 & 1 \\
\hline Antão Vaz & White & 2.067 & 1 \\
\hline Trajadura / Treixadura & White & 1.784 & 1 \\
\hline Azal & White & 1.602 & 1 \\
\hline Alfrocheiro / Tinta Bastardinha & Red & 1.514 & 1 \\
\hline Malvasia Preta & Red & 1.427 & 1 \\
\hline Viosinho & White & 1.266 & 1 \\
\hline Moscatel Galego Branco / Muscat à Petits Grains & White & 1.190 & 1 \\
\hline Tinta Carvalha & Red & 1.185 & 1 \\
\hline Diagalves & White & 1.167 & 1 \\
\hline Bical / Borrado das Moscas & White & 1.162 & 1 \\
\hline Alicante Branco & White & 1.156 & 1 \\
\hline
\end{tabular}

Source: IVV (2016)

\subsection{Brief history of vine culture in Portugal}

In the Portuguese territory, the oldest Vitis vinifera sylvestris fossils can be dated to the Inferior Pleistocene (Pais, 1986, in Magalhães, 2008). The culture of vineyards culture dates back at least 6000 years, with signs of plantations around 2000 years B.C. (Bronze age and early Iron age) (Pais, 1989, in Bohm, 2011).

\section{Table III}

Income gains obtained with the selection of the 39 autochthonous Portuguese varieties

Ganhos de rendimento obtidos com a selecção de 39 castas autóctones portuguesas

\begin{tabular}{|c|c|c|c|}
\hline Variety & Gain & Variety & Gain \\
\hline Alfrocheiro & $16.7 \%$ & Loureiro & $38.7 \%$ \\
\hline Alvarelhão & $12.7 \%$ & Malvasia Fina & $32.2 \%$ \\
\hline Alvarinho & $21.5 \%$ & Moscatel Graúdo & $17.3 \%$ \\
\hline Antão Vaz & $31.9 \%$ & Moscatel Galego & $32.1 \%$ \\
\hline Aragonês & $20.3 \%$ & Negra Mole & $46.0 \%$ \\
\hline Arinto & $15.6 \%$ & Rabigato & $30.3 \%$ \\
\hline Avesso & $9.4 \%$ & Rabo de Ovelha & $25.0 \%$ \\
\hline Azal Branco & $20.2 \%$ & Rufete & $42.1 \%$ \\
\hline Baga & $17.6 \%$ & Tinta Barroca & $11.6 \%$ \\
\hline Bical & $19.3 \%$ & Tinta Francisca & $31.9 \%$ \\
\hline Ratinho & $14.0 \%$ & Tinta Miúda & $30.9 \%$ \\
\hline Borraçal & $16.9 \%$ & Tinto Cão & $11.6 \%$ \\
\hline Camarate & $17.6 \%$ & Touriga Franca & $1.6 \%$ \\
\hline Castelão & $14.0 \%$ & Touriga Nacional & $34.4 \%$ \\
\hline Síria & $29.0 \%$ & Trajadura & $43.1 \%$ \\
\hline Dona Maria & $22.9 \%$ & Trincadeira & $13.8 \%$ \\
\hline Esgana Cão & $91.4 \%$ & Vinhão & $17.8 \%$ \\
\hline Fernão Pires & $17.6 \%$ & Viosinho & $30.9 \%$ \\
\hline Jaen & $5.9 \%$ & Vital & $33.7 \%$ \\
\hline Jampal & $26.7 \%$ & & \\
\hline
\end{tabular}

The trade of wines began with the Tartessians, followed by the Phoenicians (IX century B.C.) and later by the Greeks (VII century B.C.). The latter brought to the Iberian Peninsula the Muscat and Malvasia varieties, planted in Oriental Mediterranean islands, named "Greek Wines". In that time, according to Leewarden and Jansen (1985), in Bohm, 2011), the Iberian landscape underwent important 
changes with the felling of pine and oak trees (Quercus) to make way for vineyards. Wine was present in the daily diet by around 700 B.C.

Since the II century, under the Roman Empire vineyard plantation underwent a huge development, involving: selection of varieties resulting from the colonized territories, aiming at better productivity and adaptation to climates; controlling over-productivity; sanitarian control in the fields; destemming before pressing and pressing in presses carved into the rock, (Loureiro and Cardoso, 1993); new techniques of wine preservation, for example the addition of sulphur and other substances. In that time, aromatic and strongly coloured wines were common, while the white wines were reserved for special occasions, or consumed by wealthier classes (Veiga Ferreira, in Magalhães, 2008). During the III century, the wine market was dominated by the Celts and the amphora replaced by the barrel (wood or metal) for transporting wine to Rome (IVV, 1999). The barbarian invasions of the Iberian Peninsula, in the IV century, namely by the Suevi and Visigoths in the current Portuguese territory, reinforced by the Islamic Empire in the VII century, brought in a period of stagnation in the plantation of new vines and a great number of varieties were lost. However, in the Portuguese territory this loss was diminished due to the tolerance of the majority of the caliphates, with the exception of the Almoravides and Almoines, during which the commerce of wine was forbidden. The Vitis vinifera orientalis Negr. was maintained for producing table grapes and raisins, in particular of the Muscat variety. In the Iberian Peninsula, with the support of the Religious Orders, the caliphates began to abandon the territory and the intense Christianisation period developed vine plantation and wine production for the masses. In the North of Portugal (Minho) due to the moisty weather and conditions for the use of soil, plantation of vines was maintained according to the Etruscan high systems, resulting in wines with low alcohol content and low storage capacity. The foundation of the nation by $\mathrm{D}$. Afonso Henriques, in 1143, concluded in 1249 with the conquest of the Kingdom of the Algarve from the Muslims, brought new life to the Portuguese vineyards. However, the Iberian Peninsula can't compete with other European countries, where the wine trade had been flourishing since the reign of Charlemagne. In this period, Benedictine and Cistercian monks selected well known varieties such as Pinot, Riesling, Cabernet and Traminer. In the XIII century, Bordeaux controlled the European wine market. The wines of Tokay (Hungary) and Joannesberg (Rein-Germany) were also famous. However, in the XII and XIII centuries, wines were the first product exported from Continental Portugal, by the hand of Jews and Muslims (Bohm, 2011). The market for fortified wines (from Malvasia and Muscat varieties) increases in the North of Europe, following the "Windsor Treaty", in the XIII century, and there is evidence of the export of Madeira wines, since 1456 (Magalhães, 2008). After the 100 Years War, the devastation of vineyards in France, increased the demand for Portuguese wines, in particular in England, and facilitated the acquisition of large vineyard domains in Portugal by European investors, benefiting from privileges similar to those of colonized territories.

During the discoveries, Portuguese wines reached all continents, with the "Round" or "Back Voyage" wines achieving fame, experiencing new aging techniques, improved over the following centuries. In the $\mathrm{XV}$ century the addition of sulphur to wines, to maintain grape flavour and benefit conservation and transportation, linking the health of vines to the quality of the wines is permitted in Bourgogne.

In the XVII century, with the closing of exportation ports in France, new exporting ports (feitorias) for wines were created in Portugal, namely Viana do Castelo (where the Alvarinho wine from MonçãoMelgaço was paid for with codfish), Oporto (Port Wine), Lisbon (Muscat of Setúbal) and in the Madeira Island (Malvasia) exclusively for fortified wine, similar to Sherry (Jerez, Spain). From the island of Pico (Azores), the exportation of the Verdelho to the court of the czars of Russia proved to be a success. In the XVIII century, the "Methwen Treaty" (1703) established a protected regime for the importation of Portuguese wines in England, in particular Port Wine, produced in the Douro Region. This Region saw the creation of the General Agriculture Company of Vines from the Alto Douro and the establishment of the first geographical demarcation of Port Wine and Wines of Alto Douro (royal charter of $10^{\text {th }}$ September 1756), under the leadership of the Marquis of Pombal, prime-minister in the kingdom of D. Joseph I. This charter regulates the first property register and controls the exportation wines, divided in two categories: fine wines, or wines of the feitoria, mainly exported to England and Northern Europe (Hanseatic League), and ramo wines, exported to Brazil and other Portuguese colonies (Johnson, 1999 in Bohm, 2011). These circumstances bring an autonomous regulatory framework to the Alto Douro Region and to the Port Wine, which still exists today.

In the second half of the XIX century plagues arrived from North America, namely the powdery mildew Erysiphe necator (Schwein) (Figure 4), philloxera ${ }^{4}$ (Daktulosphaira vitifoliae (Fich) ${ }^{5}$ (Figure 5) and 
mildew (Plasmospora viticola), almost completely devastated the vineyards of Europe and large territories in Portugal. The fact that these plagues reached the Iberian Peninsula later gave some advantage to the local vines and wines, especially the wines of La Rioja (Spain), which were exported to Bordeaux (France).

${ }^{4}$ Powdery mildew was initially combated with cooper sulphate and Bordeaux syrup, but was only effectively eliminated with the discovery of phytopharmaceuticals, towards the end of the XX century.

${ }^{5}$ The mildew was combated with sulphur and the philloxera bypassed with rootstocks of American vines, namely: Vitis riparia, Vitis berlandieri e Vitis rupestris, used as "roots" onto which the European endemic varieties (Vitis vinifera) were grafted (Bohm, 2011).

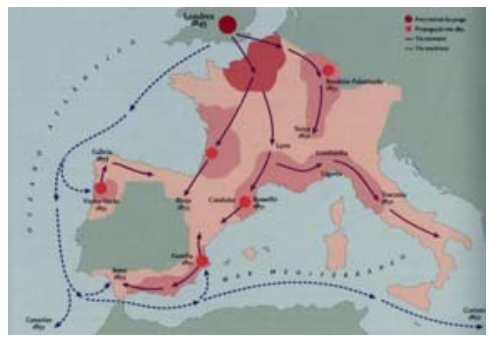

Figure 4. Diffusion of powdery mildew (Erysiphe necator (Schwein)) in Europe. Adapted from Bohm (2011).

Difusão do oídio (Erysiphe necator (Schwein)) na Europa.

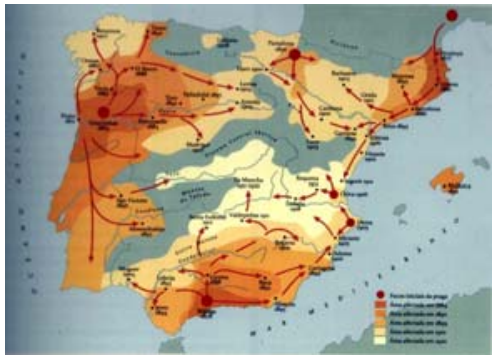

Figure 5. Diffusion of philloxera (Daktulosphaira vitifoliae (Fitch)). Adapted from Bohm (2011).

Difusão da filoxera (Daktulosphaira vitifoliae (Fitch)).

At the end of the XIX century, early XX, once the plagues were gone, a new concept of viticulture was born, namely the denomination of origin, which links wines to the regions where they are produced, as well as the definition of the type and quality of wines. In Portugal denominations of origin were drawn up in 1907/1908 for the following wines/regions: Vinho Verde, Dão, Colares, Carcavelos, Moscatel (Setúbal) and Madeira. These new rules and technical specifications pertaining to vine plantation affected and changed the European and Portuguese landscapes: reducing the vine area, reducing existing varieties and plantation of recommended varieties, introducing hybrids, grafting in the vineyards, terracing of steep slopes, cowling and mechanization of cultural operations, among others.

During the Estado Novo (1926-1974) regime, new experimental fields appear in the Portuguese regions, as well as new organizations: cooperatives, forums and state centres of a cooperative nature (Viniculture Federation of Central and Southern Portugal, in 1933 and the Junta Nacional dos Vinhos, in 1937). Since 1986, when Portugal joined the European Economic Commission (EEC), the national organisation which coordinates the wine sector was renamed as Instituto da Vinha e do Vinho (Institute of the Vine and the Wines).

In the case of the Alto Douro and Port Wine, during the dictatorship, state intervention also increased, leading to the creation of the Export Pole of Vila Nova de Gaia (1926), aiming to fix and control the warehouses and wines export, and to stop direct trade from the producing region. In 1932, the cooperative regime organized the Grémios da Lavoura to serve as counterparts and created the Casa do Douro (The Douro House). In the next year, the Instituto do Vinho do Porto (IVP) was founded as public service, renamed after 2007 as Instituto do Vinho do Porto e do Douro (IVDP), tasked with protecting and controlling wine production, and promoting research to implement the quality of vines and wines, promote the wines and update the vine registers. In the specific context of the Douro Region, the IVDP also controls the attribution of the benefit, authorizing for use part of the must produce in the manufacture of Port Wine ${ }^{6}$. The Association of Port Wine Bottle Producers was also created to defend the direct exportation form the estates of the producing region. Recently, huge investments in the Douro Region have been made, increasing the volume of the estate bottle wines through fusions between producers, new acquisition of quintas and more liberal rules for the sector (Martins Pereira, 2015).

Portugal's admission to the EEC and adoption of regulations for the viniculture sector, reinforce the concept of "Denomination of Origin" and introduce the concept of "Geographical Indication", equivalent to the Portuguese concept of "Regional Wine", also considered in the community rules. These qualitative designations are used to attach regional products to the producing area, according to its specific natural and human factors. These products are controlled by particular rules to ensure authenticity and quality. The Regional Viticulture Commissions, as Certificated Entities, ensure the certification and control of the regional products coming from those "Denominations 
of Origin" and "Geographical Indications". Today there are 12 regulated "Geographical Indications" (PGI) in Continental Portugal and 26 "Denominations of Origin” (PDO), to which should be added 5 "Denominations Origin" and 2 "Geographical Indications" in the islands of the Azores and Madeira (Figure 6). according to the classification of the "Punctuation Method", created by engineer Moreira da Fonseca (Portaria n ${ }^{\circ}$ 413/2001 de 18 de April).

${ }^{7}$ The PDO and PGI of the wine sector must be recognised and registered by the European Union (EU) in conformity with the sector's norms as established by the Commission. The PDO and PGI integrate a single sector registration and the E-BACCHUS community database, which also includes a list of the protected PDO and PGI of non-European countries, based on bilateral agreements about wine trade between the $\mathrm{EU}$ and those countries (Reg. (EU) $n^{\circ} 1308 / 2013$ ). In Portugal, the certification and control of vines is managed by the Instituto da Vinha e do Vinho, IP.

${ }^{6}$ The quantity of must depends on the qualitative potential of the parcels, going from the letter $\mathrm{A}$ to the letter $\mathrm{F}$, corresponding to an established price,

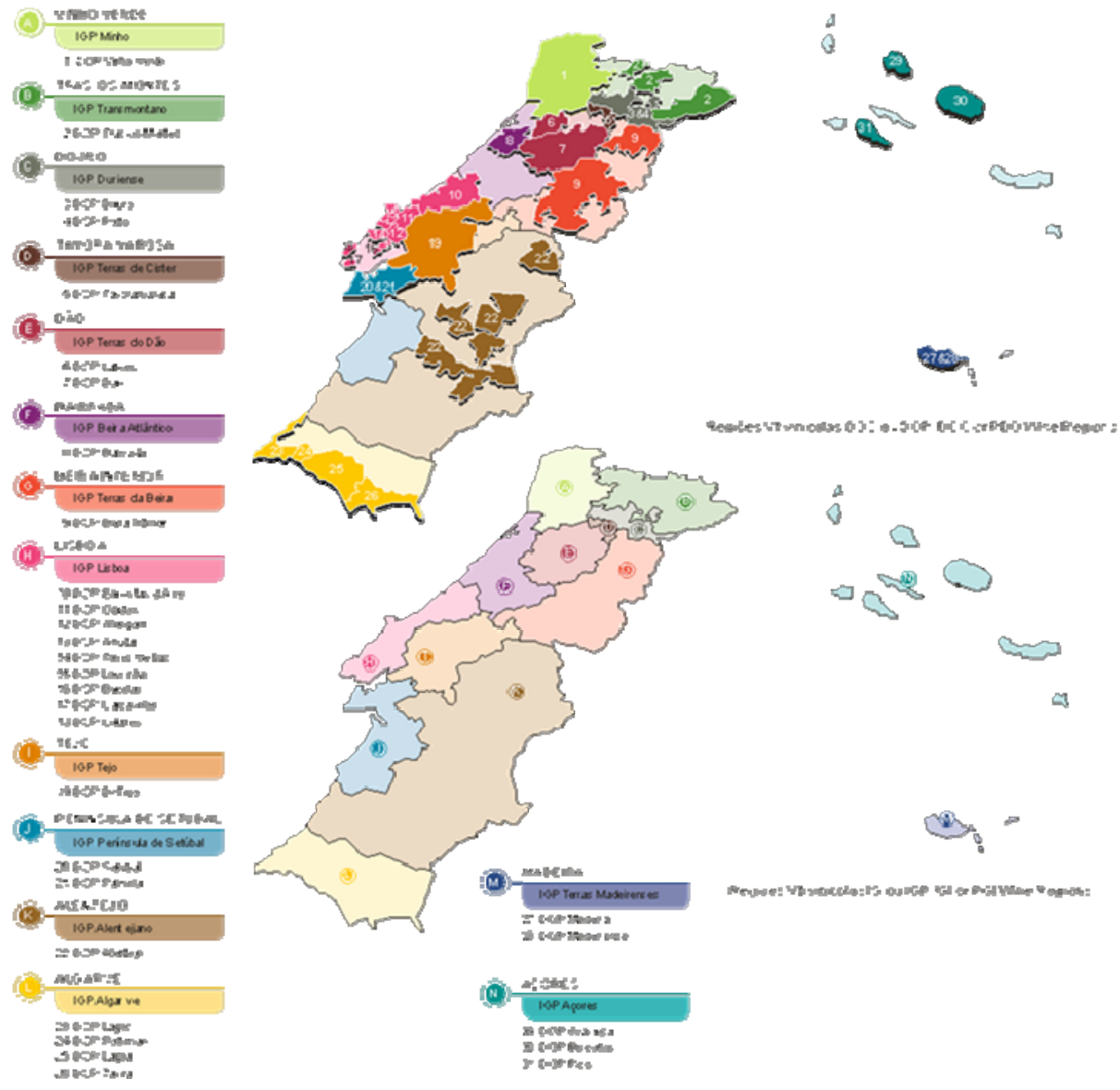

Figure 6. The Portuguese Geographical Indications and Denominations of Origin (IVV, 2016).

Indicações Geográficas e Denominações de Origem, em Portugal.

Over the past years, the European wine market has had to face the global market and increasing competition from wines with an interesting price/quality relation from the USA, Chile, Argentina, Australia, South Africa and New Zeeland, where the growing productivity by plantation area collides with the European traditional cultivation rules, environmental safeguards and working codes. Europe gains by using the quality of wines and keeping the vine terroirs rules involved in PDO and PGI classifications, which are particularly advantageous in Portugal. Indeed, despite the reduced vine surface (Table IV), the fourth country in terms of relative viticulture area (8.4\%), exceeded by Spain (36.1\%), France (28.3\%) and Italy (27.7\%) (IVV, 2015), Portugal profits from varietal diversity. The quality of the work developed by the sector: replacement of old vines, varieties renovation, acquisition of clonal and 
polyclonal materials, application of new technologies, namely watering systems (Vitis Plan, Decreto-lei $\mathrm{n}^{\circ}$ 83/97, of April $9^{\text {th }}$ ). The growing connection between production, science, professional qualification and marketing, along with more accurate private investments, should also be mentioned.

The modernisation process involves overcoming risks from the use of new cultural mechanized practices and the use of synthetic drugs for plants, both in collision with the long-time relation between the environment, the vineyards and the farmers. It is important to restore damaged ecosystems and to search for better environmental responses, able to preserve the vineyard regions' history and identity. It is also fundamental to achieve more resistant genotypes, with better productions and adaptation to each territory. The trends of Organic Viticulture and Biodynamic Viticulture go in that direction.

Table IV

Vineyard area in Portugal

Superfície vitícola de Portugal

\begin{tabular}{|c|c|c|c|c|}
\hline \multirow{2}{*}{ Regions } & \multicolumn{4}{|c|}{ Area (ha) } \\
\hline & PDO* & PIG* & $\begin{array}{c}\text { without } \\
\text { PDO/PIG }\end{array}$ & Total \\
\hline Minho & 17.323 & 1.213 & 2.482 & 21.019 \\
\hline Trás-os-Montes & 458 & 394 & 13.527 & 14.380 \\
\hline Douro & 39.824 & 157 & 2.784 & 42.766 \\
\hline Beira Atlântico & 2.138 & 203 & 12.743 & 15.086 \\
\hline Terras da Beira & 903 & 1.081 & 13.702 & 15.687 \\
\hline Terras de Cister & 496 & 794 & 1.229 & 2.520 \\
\hline Terras do Dão & 4.238 & 372 & 10.035 & 14.646 \\
\hline Lisboa & 966 & 6.808 & 11.411 & 19.186 \\
\hline Tejo & 1.095 & 2.185 & 9.593 & 12.873 \\
\hline Setúbal Península & 2.424 & 2.432 & 2.345 & 7.202 \\
\hline Alentejo & 13.683 & 6.160 & 3.532 & 23.375 \\
\hline Algarve & 76 & 274 & 1.372 & 1.722 \\
\hline Total Continental & 83.624 & 22.073 & 84.755 & 190.466 \\
\hline Açores & 181 & 10 & 1.509 & 1.700 \\
\hline Madeira & 299 & 0,5 & 753 & 1.052 \\
\hline $\begin{array}{l}\text { Total Autonomous } \\
\text { Regions }\end{array}$ & 480 & 10.5 & 2.262 & 2.752 \\
\hline TOTAL & 84.104 & 22.084 & 87.017 & 193.219 \\
\hline
\end{tabular}

Source: IVV, 2016; Situation as of 31/07/2016; * Declared production area.

\section{The landscape as an opportunity for the wine regions and wines}

2.1. The landscape and the terroir, fundamental concepts in regional development

From an integrated and interdisciplinary perspective, the concept of landscape is composed of the environmental, social, economic and cultural dimensions linked to a territory. In fact, according to the European Landscape Convention (ELC) "Landscape means an area, as perceived by people, whose character ${ }^{8}$ is the result of the action and interaction of natural and/or human factors"; (CE, 2000), it is a dynamic and evolutionary system. From this perspective, landscape is a territorial resource defined by the local (absolute position) and the involving area (relative position), adding historical and identity attributes produced by a community (place). This definition can be traced to the postmodern phenomenological currents related to the social sciences, that defines landscape as a medium between the subject and the environment, representing living space, perceived space and represented place, according to sensibility and life experiences of each individual (Assunto, 2011), as well as with the human actions, historical memory and the reflex of collective identity (Cosgrove and Daniels, 1988; Smith, 1991 in Kucan, 1999; Gaspar, 1993; Ribeiro, 1999; Cosgrove, 2004; Duncan, 2004).

The definition presented by the ELC represents a shared and strategic vision which should be taken into account when planning and managing wine producing territories which require qualification. With this considerations in mind, it is necessary to: a) to identify and define the elements of a territory (landmarks), which are considered values for the wine regions (Lavrador, 2011); b) to implement sustainable actions for the protection and restoration of those landmarks and, eventually, to create new values, according to the resulting changes of social, economic and ecological processes; c) to formulate quality objectives for each particular landscape, taking into account the opinions of specialists and of the local population. In Portugal, in the case of the denominations of origin classified by UNESCO the application of the ELC rules are real and the results can be observed on the ground, in most of the other wine regions, landscape has only recently been taken into account in regional and local development, yet the ELC was adapted into Portuguese legislation in

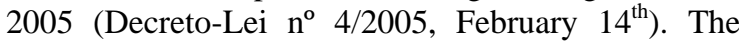
studies to insert landscape into the different stages of Local Management Plans involve: analysis, diagnosis, proposals and measures, under the scope of an integrative and coherent methodology (Oliveira et al., 
2011). However, in the case of wine regions, specific measures are needed, namely because the landscape concept is firmly attached to the concept of terroir. Both are multifaceted, systemic and dynamic concepts, even though they are not always equally represented in territorial scales: the landscape applies to medium and large scales $(<1 / 50.000)$, the terroir always represents large scales $(<1 / 25.000)$. In a strict sense, the terroir concept represents a unique and delimited (zoning) geographical area with particular physical conditions - geomorphology, climate and soil - where particular viticulture practices are applied, resulting from selected techniques and strategies used in viticulture and wine production, carried on through the centuries by local population. In a general sense, the concept terroir concept reflects the identity, expression of authenticity, endogenous potential, heritage (ecological and cultural), the relations between humans and nature, the heritage resulting from the collective knowhow and its evolution, symbolising the transcendental and historic consciousness (Foucault, 1970, in Gay et al., 2000), that makes the wine regions unique and gives the wines their quality and singularity (Saulle, 2006) (Figure 7).

Regarding this connection, the authenticity and the quality of landscapes and terroirs and the quality of the resulting products has to be broached in the planning and management plans, especially considering the stakeholders and local's opinions. It is also crucial to bear in mind the lessons learned from the sustainable development paradigm, namely traditional viticulture and precision viticulture, environmental risks, wine control and security, as defended in the principles of the International Letter of Fontevraud ${ }^{9}$ (ICOMOS, 2003).

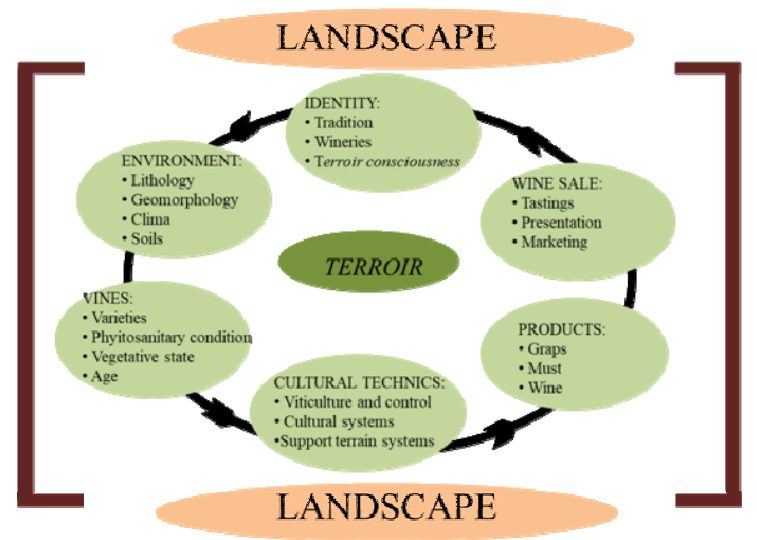

Figure 7. Landscape and Terroir intercepting concepts. Adapted from Sotes in Bohm(2011).

Paisagem e Terroir conceitos que se cruzam.
2.2. The role of brands in the marketing of wines and wine regions

The creation of the Wines of Portugal/Vinhos de Portugal brand ("WOP", WP, 2010) $)^{10}$ aims to be an important contribution to the wines promotion and to bring added value to the Portuguese wine products. Its creation is due to the fact that "Portugal lacks an image as a producer of qualified wines”, according to studies involving British and American consumers (IVV, 2015). The "WOP" brand is composed of a logo and the signature "A world of difference" (Figure 8), which intends to underline the values inherent to Portuguese wines, the complexity, authenticity, varieties, terroir and regions, which make them unique.

${ }^{8}$ Landscape character - particular relief, vegetation, soil use and settlement, which give a particular unity to a territorial area.

${ }^{9}$ International Charter of Fontevraud, 2003 - Aims at the protection, development and management of the wine regions, and has been signed by the Minister of Ecology and Sustainable Environment, by the Institute of Denominations of Origin, by the Mission of the Loir Valley and by the International Bureau for Vines and Wines (France).

${ }^{10}$ The "WOP" brand results from the joined work of institutions - Instituto da Vinha e do Vinho, I.P (IVV), the Instituto dos Vinhos do Douro e do Porto I.P. (IVDP), ViniPortugal, the Regional Viticulture Commissions (CVR), ANDOVI e IVBAM, IP - and the collaboration of producers and merchants, among others. Strict rules are necessary for the use of the "WOP" brand in order to ensure its correct use as public value, meaning, to be able to represent the wine sector and Portugal in the international markets (Portaria $n^{\circ} 6237 / 2011,11.04 .11$ e n $741 / 2015,23.01 .15$ ).

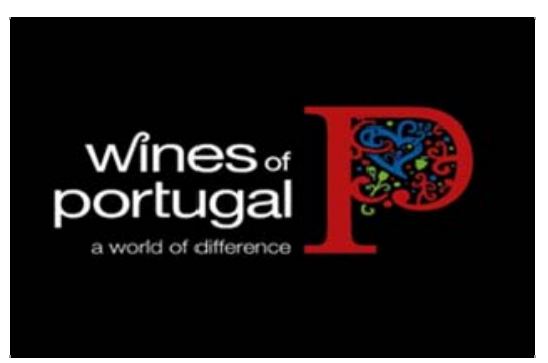

Figure 8. The Vinhos de Portugal/Wines of Portugal brand is composed of the WOP logo and the signature "A word of difference”. www.winesofportugal.info (Consulted in August 2015).

Logótipo "WOP" e assinatura "A word of difference" da marca Vinhos de Portugal

Today there is a strong tendency to link the quality of wines to the landscapes from which they originate (Inácio, 2009; Tempesta et al., 2010). The five most important Portuguese demarcations of origin - Vinho Verde, Porto and Douro, Dão, Bairrada and Alentejo, have been subject to perception ${ }^{11}$, market ${ }^{12}$ and representation $^{13}$ studies, in order to recognize landmarks and to discuss their role in the region and wine marketing (Lavrador da Silva, 2008; Lavrador 2011). In the representation study, regarding iconography, this study also proves a reduction in the 
use of landmark images in wine promotion, when compared to representations of the wine brand and other dimensions related to tourism. In the case of the PDO "Vinho Verde", one of the most traditional regions of the country, with a strong identity, respondents identified manor houses and estates as regional main landmarks, over and above other traditional or modern charismatic elements, such as the bocage mosaic and the vines on the edges of the fields, other "high system" structures, traditional and modern cellars, stone walls and stone (granite) supporting pillars for the vineyards, traditional varieties (such as Alvarinho), among others. In fact, this region has undergone major changes in the landscapes, namely a loss of diversity and singularity, with the destruction of the bocage mosaic and related vineyards support systems, reduction of varieties, technological improvement and expansion of vineyard areas. This landscape changes represent modernization but can also compromise remarkable promotional regional values. Criteria and imagination are required to stop the disappearance of the "high systems" and lytic borders in the promotional features and management actions. On the contrary, traditional elements should be used in places and functions out of the fields, such as in the quintas or recreational areas landscaping. Considering wines, a good strategy would be to merge the image of a green landscape (resulting from the humidity and mild climate) with the idea of lightness, youth and freshness of the "Vinhos Verdes" (Figure 9).

${ }^{11}$ The perception study used a large survey (541 questions), involving 470 respondents, whose opinions have been subject to the Multiple Correspondence Factorial Analysis.

${ }^{12}$ The marking study used surveys for producers (92) and consumers (470), treated by Descriptive Statistics.

${ }^{13}$ The representation study used 260 promotional features from wine companies and tourism, analysed by the Cohens' Model (1996, in Sarmento, 2004), also treated with Multiple Correspondence Factorial Analysis.

The PDO "Porto" and "Douro" is over 250 years old is recognized as UNESCO Cultural Heritage (2001) due to the "heroic, living and evolutionary" viticulture (Bianchi-Aguiar, 2001). It is developed under a particularly adverse natural territory in the Douro Basin, carved out of shale, with deep slopes and an extreme climate. The results of the perception study indicate terraces and patamares, olive trees in the vineyard borders, mortórios (vineyards abandoned since the philloxera plague); the Douro River and the panoramic views as the main region landmarks. Secondly, and also less used as promotional images, are more recent concepts such as "vinha ao alto" (conduction vine systems perpendicular to the line curves), the consociations between vines and fruit trees (mainly olives and almonds), the quintas and the vernacular and religious heritage. Results of the representation and marketing studies indicate landscapes in the Douro region are well explored in promotion, but improvement could be made in wines marketing (Figure 10).

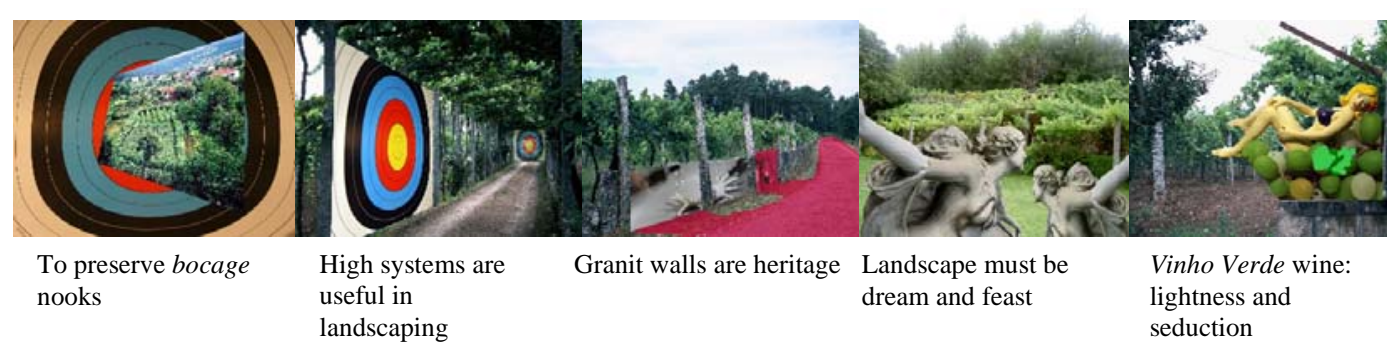

Figure 9. Landmarks of the PDO "Vinho Verde" - NW Portugal (Lavrador, 2011).

“Marcas” da paisagem da DO “Vinho Verde” - NW Portugal.

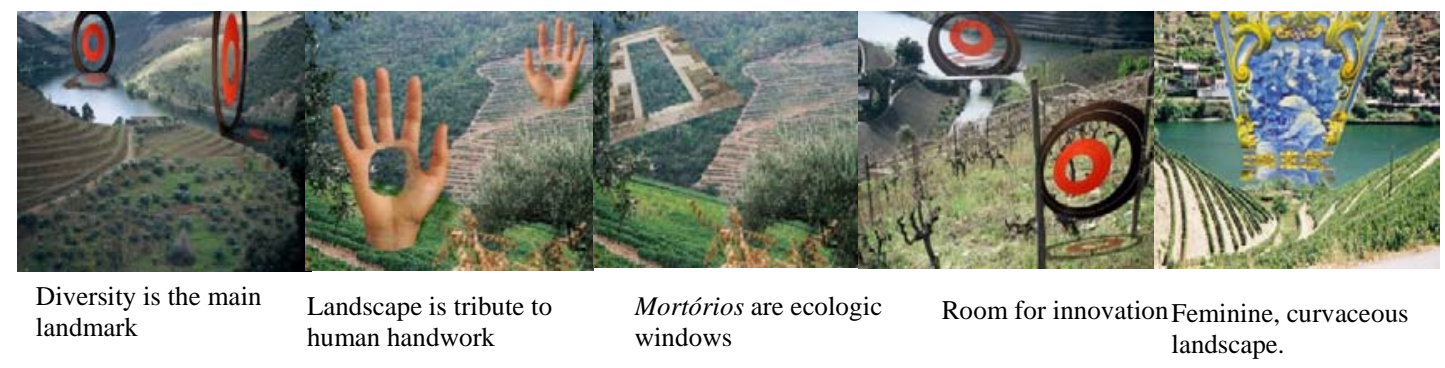

Figure 10. Landmarks of the PDO “Porto” and “Douro”(Lavrador, 2011).

“Marcas” da paisagem das DO "Porto" e "Douro". 
The mosaic character of the PDO "Dão" is characterized by vineyards unnoticeably installed between leafy forest, representing a negative regional landmark in the opinion of some producers, which emphasize the quality of the wines and of the endemic varieties, as main identity main elements. Other important heritage values, such as the granite architecture (manner houses, traditional cellars, walls for separate fields), the archaeological (millenarian lagaretas - open air cubes in granite for making wine and olive oil), the social and historical values (cooperatives), are secondary regional landmarks, according to the respondents. Natural values such as the amount and quality of thermal water springs has also been forgotten, including its regional economic value. It is important to link wines and waters in new tourism offers and marketing ideas (Figure 11).

In the PDO "Bairrada" the main landmarks identified in the referred studies are forest, cellars and cooperatives. Other landscape elements are selected as secondary landmarks, namely: vineyards within forests (similar to the "Dão" landscapes), the Baga variety and the soils (clays and marls) and modern cellars with signature architecture. The respondents also highlight the particular association between gastronomy (suckling pig) and wines, immaterial heritage (carnival) and thermal waters, also unconnected with wines (Figure 12).

In the PDO "Alentejo", landmarks are better recognized and promoted, with the "seas of vines", the plain, the traditional cellars, the montado (agrosylvan-pasturage system with huge regional and national ecological and economic value) and the riverside villages by the Alqueva dam, being greatly explored in tourism features. Other important elements of the region are seen as secondary, as common large propriety and producer fields, the montes (isolated rural houses), the monumental, archaeological and vernacular heritage, the Alqueva dam (the largest artificial lake in Europe) and modern cellars (Figure 13).

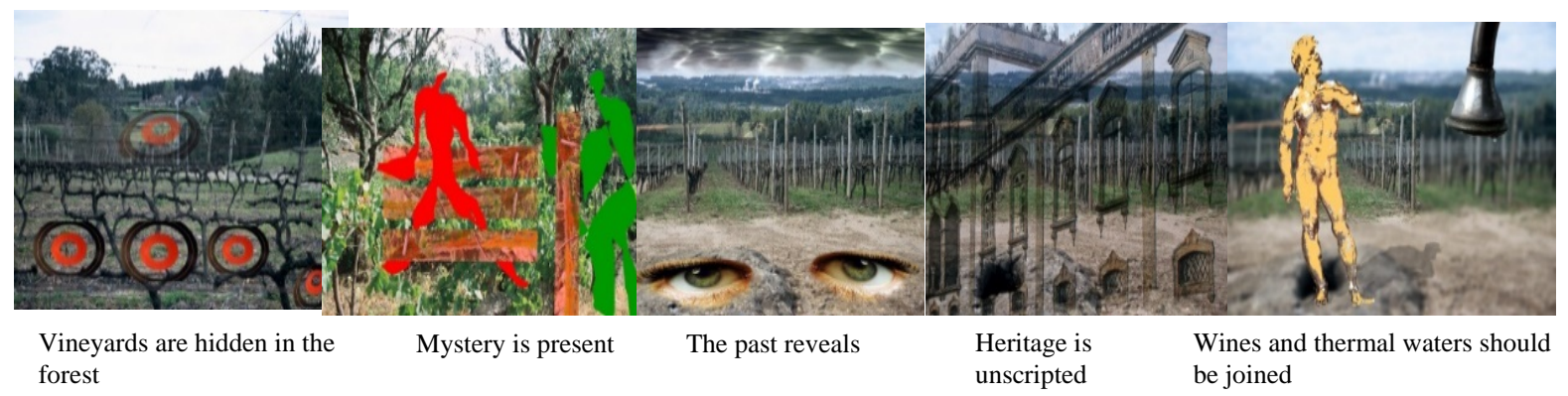

Figure 11. Landmarks of the PDO “Dão” - Interior Centre Interior of Portugal (Lavrador, 2011).

“Marcas” da paisagem da DO “Dão” (Interior Centro de Portugal).

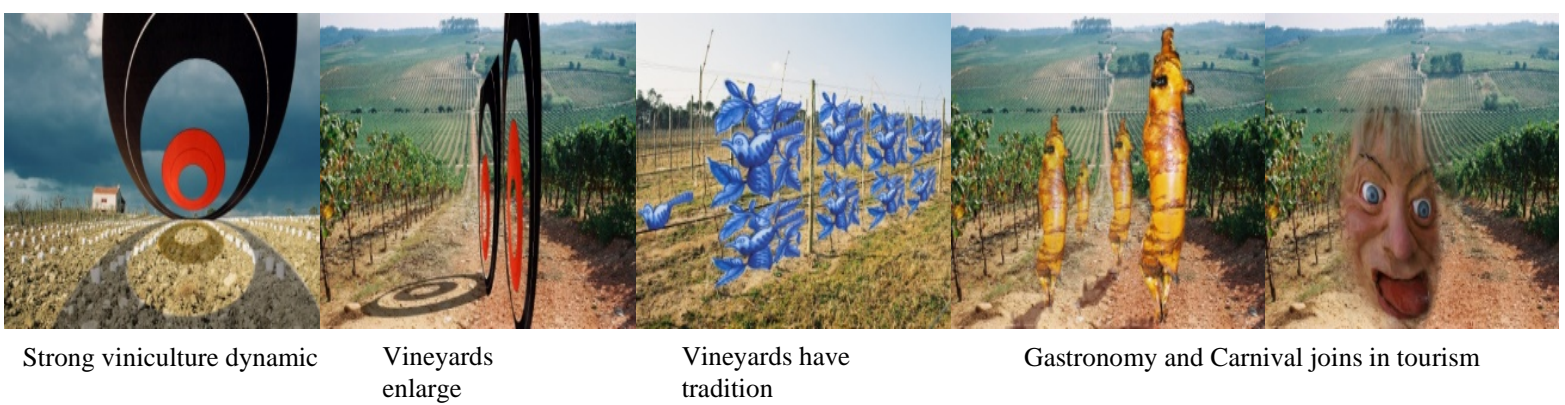

Figure 12. Landmarks of the PDO "Bairrada" - Centre Littoral of Portugal (Lavrador, 2011).

“Marcas” da paisagem da DO "Bairrada” - Litoral Centro de Portugal 


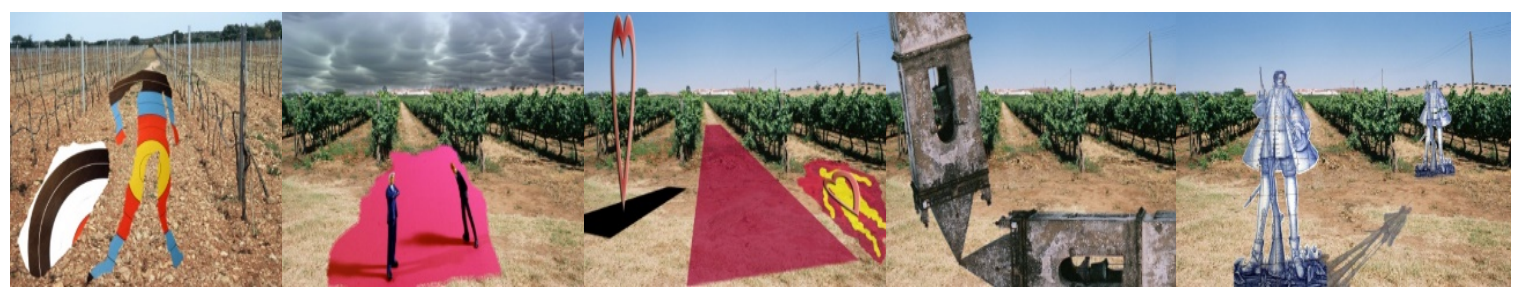

The” seas of vines” renovation The vines and wines move interests and icons passions

Heritage and hunting sum up tourism potential

Figure 13. Landmarks of the PDO “Alentejo” - Southern Portugal (Lavrador, 2011).

“Marcas” da paisagem da DO “Alentejo" - Sul de Portugal.

\section{The landscape in tourism development of the wine regions}

\subsection{Wine tourism, a niche still taking off in Portugal}

Portugal has a huge potential in wine tourism. There are wine regions all over the country, as well as modern and qualified wine equipment and installations ${ }^{14}$ and the growing offer of wine services and products in less populated areas and all seasons, benefiting the regional development and boosting tourism. However, wine tourism is a relatively recent activity in Portugal: $78 \%$ of the companies initiated their activity after 2000, 27\% of which between 2010 and 2013 (Turismo de Portugal, 2014). A coordinated support network for wine tourism is needed and there are still functional problems with the established itineraries, such as in terms of marketing.

In the wine tourism world pride of place goes to visits to the wine companies and vineyards and participation in wine related events, resulting from the intention to become familiar with the regions and taste the wines (Hall et al., 2000). However, wine tourism should offer other products, considering there is a demand for more diversified experiences (Frochot, 2005; Kastenholz, 2010; Lavrador et al., 2012). In that sense, values such as landscape, terroir and identity are important in the attraction and qualification of tourism experience (Maby, 2003), as stated in the several recommendations and conventions of UNESCO, in defence of the "spiritu loci” (ICOMOS, 2008, in Lavrador, 2011-a). Cultural traditions, methods of production of wines and other authentic culinary products (Hall et al., 2000), including unconventional and diversified experiences (Laine, 2005), able to enrich knowledge, and its articulation are frequently mentioned by tourists as strong attractions (ICOMOS, 1976), however these are still little implemented in the Portuguese wine regions (Simões, 2003). Today there are challenges associated to rural tourism, involving the increase in tourism agents and activities, the rise in consumption patterns and an increase in tourism demand. This pressure gives rise to a mass of niche markets (wine tourism, religious tourism, activity tourism, others) and different ways of doing tourism (week-end, miniholidays, individual or in small or large groups), that need sustainable strategies, rooted in diversity, creativity and quality, connected with landscape and identity values (Carneiro et al., 2015). Those strategies require looking to landscapes as a social process which should be closely linked to participation in territory planning and management. A governance perspective is needed, as well as a shared vision for the future between all stakeholders and those who take advantage of the territories (Table V).

\footnotetext{
${ }^{14}$ In Portugal, the wine tourism units are those which produces wine, host visits to the vineyards and market wines in their offices. These include Port Wine cellars and some cooperatives, although they do not offer all three of the aforementioned services (Turismo de Portugal., 2015).
}

\subsection{Itineraries with landscape and literature: The Roga Route (Douro)}

Itineraries are one of the most common wine tourism offers. Currently they are associated to high quality production areas (PDO) and aim at involving the visitor with cultural features linked to the wine production process and guided visits to the vineyards. The association between landscape and other cultural values such as literature and poetry could offer unique experiences, and moments of well-being and learning through physical or virtual visits. At the level of active citizenship, cultural itineraries help to develop innovative visits, and more adjusted attitudes and behaviours targeting the territories sustainability, and therefore quality.

The literary Roga Route ${ }^{15}$ is based on the best-seller Vindima (Harvest) (1945), by Portuguese author Miguel Torga, which describes the $40 \mathrm{~km}$ marches by workers along the Alvão Mountain to the Quinta da Cavadinha (Sabrosa-Douro) and their life during the harvest season. The aim is to create a sensorial and 
interactive itinerary, in which selected literary excerpts of the book should be read (Figure 14).

${ }^{15}$ The literary excerpts used on the itinerary come from the Data Base of the Project "Atlas of the Literary Landscapes of Continental Portugal", by the Instituto de Estudos de Literatura e Tradição, Faculdade de Ciências Sociais e Humanas, Universidade Nova de Lisboa. It has the support of a multidisciplinary team that works under the umbrella of the Ecocriticism (Queiroz, 2010). The cultural itineraries use the following steps: diagnosis of elements of the material territory (involving natural, socioeconomic, heritage, historic, cultural values) and immaterial values (traditions, ethnography, symbols, dances, legends, others).

Table V

Landscape in the management and tourism development of wine regions

A paisagem na gestão e desenvolvimento turístico das regiões vitivinícolas

\begin{tabular}{ll}
\hline I - Management strategies & II - Experiences and emotions \\
\hline $\begin{array}{l}\text { 1. History and characterization of natural and human landscape } \\
\text { elements - identity values, economic and trade potentialities resulting } \\
\text { of technical evaluation and public opinion. }\end{array}$ & $\begin{array}{l}\text { 1. Strategic experiences: wine tastings, vines and cellars experiences, } \\
\text { cultural events (literary, artistic, others), contemplation, socializing, } \\
\text { others. }\end{array}$ \\
\hline
\end{tabular}
of technical evaluation and public opinion.

2. Contribution to sustainable development, according to European

Convention principles, considering the landscape as a resource, as well

as an evaluation of the public and institutions as active stakeholders in detection of regional identity values (perception). The use of several techniques, action measures, laws and politics for the territory management, aiming the conservation, protection, requalification and creation of new and appealing territory elements for the places is

2. Innovative experiences according to the unique aspects of each place: observation experiences, environmental interpretation, meetings, artistic or creative activities (painting, reading, photography), sensorial experiences. recommended.

3. Promotion and dynamic sharing of experiences involving different opinions: planning technicians, politics, local and regional stakeholders and tourism visitors. It is important to take into account complementary experiences with other regions.

4. Implementation of measures and actions, such tourism itineraries, including wine tastings and gastronomy, environmental or literary routes, others.

Adapted from Carneiro et al. (2015).

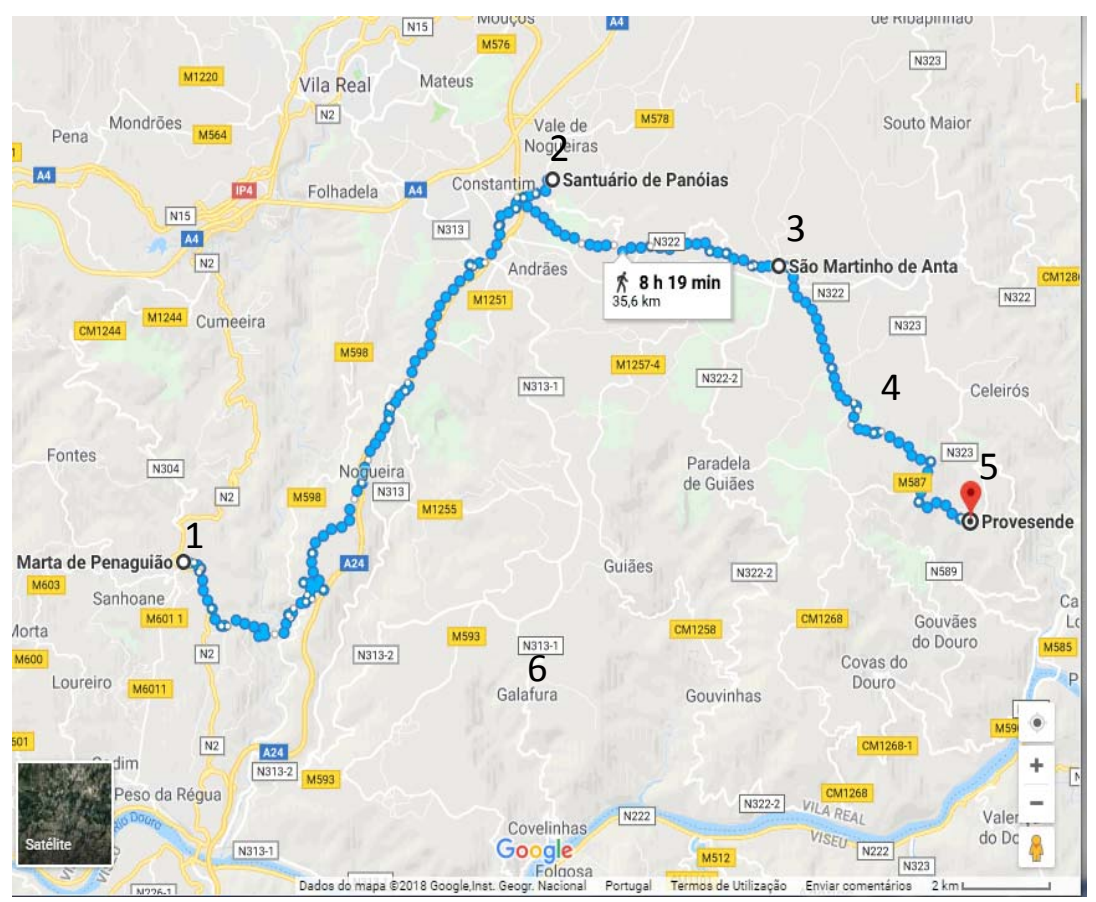

1. Santa Marta de Penaguião - Maps distribution and geographical information about the Douro River Valley

2. Panóias (religious place) - Information about meanings and functions of the archaeological relics

3. São Martinho de Anta - Visit to the house where Miguel Torga was born, and wine tasting

. Paços - Leisure exercise of the PDO "Porto" and "Douro" landscapes

5. Quinta da Cavadinha - Visit to the vineyards and cellars and tasting of a typical meal

6. Miradouro de São Leonardo de Galafura (extra) - Creative writing Workshop (or drawing/painting according to the visitor’s interests).

Figure 14. The Roga route, an itinerary with landscape and literature in the Douro (Lavrador and Tavares, 2015). A Rota da Roga, um itinerário com a paisagem e a literatura no Douro. 


\section{CONCLUSIONS}

The vinicultural heritage of Portugal and the value of the wines and wine regions' landscapes are an important dimension for the country's economy. This importance is the result of the unquestionable varietal heritage, the history, quality and the singularity of the Portuguese wine regions' landscapes, whose potential should be urgently mobilized in terms of tourism. Portugal currently benefits from important projects in the viniculture sector, namely concerning the preservation and qualification of its varietal heritage, led by the Portuguese Association for Vine Diversity /Associação Portuguesa para a Diversidade da Videira (PORVID), which are internationally recognized. There are also innovative proposals associated to wine companies that follow the indications of the present European Agricultural Policies, defending a multifunctional rural world, namely the complementary between products and associated services. In this sense, and for the wine regions, it is important to associate the quality of wine production to the specificity and sustainability of the terroir where the wines are produced, as well as the singularity of the involving landscapes. Together, these features allow for the implementation of diversified tourism offers, resulting from unique and adjusted experiences in the vineyards and cellars. In the UNESCO heritage Denominations of Origin - PDO "Porto" and "Douro" and PDO "Pico" (Azores), the requirements of the classification and the hard work required for qualification facilitate the development of innovative projects. Other projects must be implemented in the other demarcated regions, and this implies taking landscapes into account in the planning and management instruments. The definition of Landscape Quality Objectives is crucial for this target, and integrative public policies, involving public opinion and the interests of the different stakeholders, are an essential factor. What is also fundamental is a policy centred on the territory, instead of sectorial divided, in particular for the

\section{REFERENCES}

Arroyo-García R., Ruiz-García L., Bolling L., Ocete R., López M. A., Arnold C., Ergul A., Söylemezo”lu G., Uzun H. I., Cabello F., Ibáñez J., Aradhya M. K., Atanassov A., Atanassov I., Balint S., Cenis J. L., Costantini L., Gorislavets S., Grando M. S., Klein B. Y., Mcgovern P. E., Merdinoglu D., Pejic I., Pelsy F., Primikirios

N., Risovannaya V., Roubelakis-Angelakis K. A., Snoussi H., viniculture and tourism sectors. These combined initiatives benefit the construction and implementation of innovative projects, sustained by public and private institutions, research centres, Comunidades Intermunicipais/Intercounty Communities (CIM), Municipalities and public institutions (IVV, IVDP, TP), official private-law associations (CVR), organizations and companies. New attitudes and behaviours are needed on the part of producers and tourism agents, involving more cooperation and articulation and support for eventual candidacies to achieve financing and to analyse risks. Regarding producers, motivating events are needed to highlight the advantages of using good viticulture practices and multifunctional business management. More studies and concrete proposals with innovative ideas are welcome, in order to explore cultural, environmental and identity values (literary itineraries being a good examples) and the landscapes are an important resource in this direction, perhaps the stronger link between viniculture and tourism sectors. The identification, through technical studies involving the different stakeholders, of landmarks as identity symbols of the wine regions, is an important step to decide what, who and where territory elements must be protected and qualified, using planning and management instruments and rules. The definition of landmarks also helps the wines and the wine regions promotion, both profiting of precise representations, that expresses the singularity and quality of the regions, in respect for the work of the ancestors but adjusted to the new circumstances and ambitions, taking into account a prosperous, balanced and sustainable future. A riskier approach from an artistic point of view to advertising and promotional images is also necessary, in parallel with the images used in the marketing of the wines' brands. At a national scale, the brand Vinhos de Portugal/Wines of Portugal (WOP) goes in that direction, involving elements of the Portuguese culture and heritage values in the wines marketing image, recognizing the economic importance and of wines and their value to producers, institutions and the country's prestige.
Sotiri P., Tamhankar S., This P., Troshin L., Malpica J. M., Lefort F. and Martinez-Zapater J. M., 2006. Multiple origins of cultivated grapevine (Vitis vinifera L. ssp sativa) based on chloroplast DNA polymorphisms. Mol. Ecol., 15, 3707-3714.

Assunto R., 2011. A paisagem e a estética. In: Filosofia da Paisagem, uma Antologia. 339-341. Universidade de Lisboa. 
Bianchi-de-Aguiar F. (coord.), 2001. PIOT-ADV, Relatório da Candidatura do Alto Douro Vinhateiro a Património Mundial, Plano Intermunicipal de Ordenamento do Território do Alto Douro Vinhateiro (PIOT-ADV). UTAD e CCDR-N, Porto.

Bohm, J., 2011. Atlas das Castas da Península Ibérica, História Terroir, Ampleografia. 234 p. Dinalivro, Portugal.

Carneiro M. J., Lima J., Lavrador A., 2015. Landscape and the rural tourism experience: identifying key elements, addressing potential and implications for the future. Journal of Sustainable Tourism. Routledge, Registered Number: 107295, DOI: 10.1080/09669582.2015.1037840 (Online) Journal homepage: http://www.tandfonline.com/loi/rsus20

Conselho da Europa, (CE) 2000. Convenção Europeia da Paisagem, Decreto n. ${ }^{\circ}$ 4/2005 (D.R. n. ${ }^{\circ}$ 31, Série I-A de 2005-0214), Florença, Itália.

Cosgrove D., 2004. A geografia está em toda parte: cultura e simbolismo nas paisagens humanas. In: Paisagem, tempo e cultura. 92-123. UERJ (ed.), Rio de Janeiro.

Cosgrove D.E., Daniels S.J., 1988. The iconography of landscape: Essays on the symbolic representation, design and use of past environments. XX p. Cambridge University Press, Cambridge.

Duncan J., 2004. A paisagem como sistema de criação de signos. In: Paisagens, textos e identidade. 91-132. UERJ (ed.), Rio de Janeiro.

Eiras-Dias J. E., Bruno-Sousa B., Cabral F., Carvalho I., 1989. Isoenziymatic characterization of Portuguese vine varieties of Vitis. Riv. Vit. Enol. 49 (1), 89-90.

Fregoni M., 2010. Le area viticole storiche nel mondo: Il loro vitigni, la loro protezione e la tipicita' dei vini in esse ottentenuti. Proceedings of the VIII International Terroir Congress, Soave, Italy, June 2010.

Frochot I., 2005. A benefit segmentation of tourists in rural areas: a Scottish perspective. Tourism Management, 26 (3), 335-346.

Gaspar J., 1993. As Regiões Portuguesas. Ministério do Planeamento e da Administração do Território, Lisboa.

Gay P., Evans J. Rodman P., 2000. Identity: a reader. Ed. Sage Publications, London, New Delhi, Thousand Oaks.

Hall CM., Sharples L., Cambourne B., MacIonis N., 2000. Wine tourism around the world: Development, management and markets. Butterworth-Heinemann, Oxford, UK.

ICOMOS, 1976. $1^{\mathrm{a}}$ Carta de Turismo Cultural http://portal.iphan.gov.br (consulta Dezembro 2014).

ICOMOS, 2003. Charte Internationale de Fontevraud. Ministère de l'Agriculture et de la Pêche, le Ministère de l'Ecologie et du Développement Durable, l'Institut National de l'Origine et de la Qualité (INAO), la Confédération des vins du Val de Loire, l'Interprofession des vins du Val de Loire, la Mission Val de Loire et l'Organisation Internationale de la Vigne et du Vin ont contribué à son élaboration, avec le soutien de la Commission française pour l'UNESCO et ICOMOS (International Council for Monuments and Sites - UNESCO)

Inácio A. I., 2009. Enoturismo no Douro e no Alentejo: da (re)construção cultural à criação de dinâmicas territoriais locais. CEG, Lisboa.

INE, 2013. Anuário estatístico. Lisboa.

INE, 2015. Contas económicas da Agricultura, "Quadro E.1.1.3 Produção da agricultura por tipo de bens e serviços (preços correntes; anual)” - Website of the INE, in 08/09/2017).
IVV, 1999. A vinha e o vinho em Portugal, apontamento histórico. Instituto da Vinha e do Vinho, Portugal.

IVV, 2015. [http://www.ivv.min-agricultura.pt] (consulted in July 2016).

IVV, 2016. [http://www.ivv.gov.pt] (consulted in August 2017).

Jones G., 2013. Uma avaliação do clima para a Região Demarcada do Douro. Uma análise das condições climáticas do passado, presente e futuro para a produção de vinho. Ed. ADVID Associação para o Desenvolvmento da Viticultura Duriense.

Kastenholz E., 2010. Experiência global em turismo rural e desenvolvimento sustentável das comunidades locais, Proccedings of the IV Congresso de Estudos Rurais, Aveiro, Portugal.

Kucan A., 1999. Cultural landscapes as symbols of national identity. Protection or change? Agricultural Conspectus Scientificus, 64 (4), 259-268.

Laine, B. 2005. Sustainable tourism strategies: A tool for development and conservation, Interamerican. Review of Environment and Tourism, 1, 12-18.

Lavrador da Silva A. L., 2008. Paisagens de Baco: Identidade, Mercado e Desenvolvimento - Um estudo de percepção e de representação aplicado às regiões vinhateiras dos Vinho Verde, Douro, Dão, Bairrada e Alentejo. 393 p. PhD Thesis, Universidade de Évora, Portugal, July2008.

Lavrador A., 2011. Paisagens de Baco, 196 p. Colibri, Lisboa.

Lavrador A., 2011-a. Cultural and sensorial trips through Portuguese winegrowing regions. Proceedings of the XXXIV World Congress of the Vine and Wine, Porto, 20-27 June 2011. 1026-1030.

Lavrador A., Kastenholz, E., Lima J., 2012. O papel da paisagem na experiência de enoturismo - o caso de Favaios. Proceedings of the INVTUR Internacional Conference, Univ. of Aveiro, Portugal.

Lavrador A., Tavares A.C., 2015. Percursos literários: uma ferramenta pedagógica e de promoção turística. Revista Polyphonia, 23, n. 2, Dossiê "Presença e Lugar da Filosofia na Educação Básica", Universidade Federal de Goiânia, Brasil, 2015.

Lopes M.S., Kristina M., Eiras-Dias J.E., Steinkellner H., Laimer M., Câmara Machado A., 1999. The use of microsatellites for germoplasm management. A Portuguese grapevine collection. Theoretical Application Genetics, 99, 733-739.

Loureiro V., Cardoso A.H., 1993. Os Vinhos do Dão, Enciclopédia dos Vinhos de Portugal, Publicações Chaves Ferreira, S.A. Portugal.

Maby J., 2003. Modalites de constitution d'un savoir scientifique sur les paysages viticoles. Colloque International Paysages de Vignes et de Vins, 2003, Fontevraud. Paisages de Vignes et de Vins: Patrimoine, Enjeux, Valorisation. Angers: InterLoire.

Magalhães N., 2015. Tratado de viticultura. A videira, a vinha e o terroir. 607 p. 2. ${ }^{\text {a }}$ ed. Esfera Poética, Portugal.

Martins Pereira G., 2015. [www.ivdp.pt] (consulted in July 2015).

Martins A., 2009. [http://www.acenologia.com] (consulted in August 2015).

Martins A., Graça A., 2014. The Portuguese approach to the diversity of the grapevine [http://www.bio-conferences.org] (consulted in July 2015)

Oliveira R., Cancela d'Abreu A., Botelho M. J., Afonso M., 2011. A Paisagem na revisão dos PDM. Orientações para a implementação da Convenção Europeia da Paisagem. DGOTDU. Documentos de Orientação 2/2011. ISBN 978-972-8569-53-2. 
Queiroz A.I., 2010. Atlas of the literary landscape of mainland Portugal. Proceedings of the 4th EASCLE Conference Environmental Change - Cultural Change. 1st - 4th September, 2010. University of Bath, UK.

Ribeiro O., 1999. Portugal o Mediterrâneo e o Atlântico. 6a ed., Sá da Costa, Lisboa.

Sarmento J., 2004. Representação, imaginação e espaço virtual: Geografias de paisagens turísticas em West Cork e nos Açores. Fundação Calouste Gulbenkian, Lisboa.

Saulle I., 2006. La notion de terroir. Quelle(s) réalité(s). Pour quelle utilité? Le cas des jeunes adultes français, VI Congrès International des Terroir Viticoles, Bordeaux.

Simões O, 2003. A vinha e o vinho em Portugal: contributos para o desenvolvimento local e regional. In: Portugal Chão, org. José Portela e João Castro Caldas. 425 - 448 Oeiras: Celta, Oeiras.
Tempesta T., Giancristofaro R.A., Corain L., Salmaso L., Tomasi D., Boatto V., 2010. The importance of landscape in wine quality perception: An integrated approach using choice-based conjoint analysis and combination-based permutation tests. Food Quality and Preference, 21 (7), 827-836.

Turismo de Portugal (TP), 2014. Plano estratégico nacional do turismo. Revision proposals for the horizont 2015. (consulted in December 2014).

Turismo de Portugal (TP), 2015. Inquérito às unidades de enoturismo, Portugal.

UNESCO [http://www.unesco.com], (consulted in December 2011).

Wines of Portugal (WP), 2010. Manual de posicionamento da marca, Vinhos de Portugal. 